\title{
Loss of p53 Sensitizes Cells to Palmitic Acid-Induced Apoptosis by Reactive Oxygen Species Accumulation
}

\author{
Guowu Yu ${ }^{1}$, Hongwei Luo ${ }^{2} \mathbb{D}$, Na Zhang ${ }^{3}$, Yongbin Wang ${ }^{1}$, Yangping Li ${ }^{1,4}$, Huanhuan Huang ${ }^{1}$, \\ Yinghong Liu ${ }^{5}$, Yufeng $\mathrm{Hu}^{1,4}{ }^{1,}$ Hanmei Liu ${ }^{6}$, Junjie Zhang ${ }^{6}$, Yi Tang ${ }^{2, *}$ and Yubi Huang ${ }^{1,4,5, *}$ \\ 1 National Crop Science Experimental Teaching Demonstration Center, College of Agronomy, \\ Sichuan Agricultural University, Huimin Road 211\#, Wenjiang District, Chengdu 611130, China; \\ 2002ygw@163.com (G.Y.); WWYYBB007@163.com (Y.W.); yangpingli103@gmail.com (Y.L.); \\ hh820423@163.com (H.H.); huyufeng@sohu.com (Y.H.) \\ 2 Department of Regenerative and Cancer Cell Biology, Albany Medical College, Albany, NY 12208, USA; \\ LuoH@mail.amc.edu \\ 3 College of Science, Sichuan Agricultural University; Huimin Road 211\#, Wenjiang District, Chengdu 611130, \\ China; 03118663@163.com \\ 4 State Key Laboratory of Crop Gene Exploration and Utilization in Southwest China, Sichuan Agricultural \\ University, Huimin Road 211\#, Wenjiang District, Chengdu 611130, China \\ 5 Maize Research Institute of Sichuan Agricultural University; Huimin Road 211\#, Wenjiang District, \\ Chengdu 611130, China; sclydx@163.com \\ 6 College of Life Science, Sichuan Agricultural University; Xingkang Road 46\#, Ya'an 625014, China; \\ hanmeil@163.com (H.L.); junjiezh@163.com (J.Z.) \\ * Correspondence: tangy@amc.edu (Y.T.); 10024@sicau.edu.cn (Y.H.); Tel.: +1-518-262-0456 (Y.T.); \\ $+86-028-86290868$ (Y.H.)
}

Received: 20 October 2019; Accepted: 2 December 2019; Published: 12 December 2019 updates

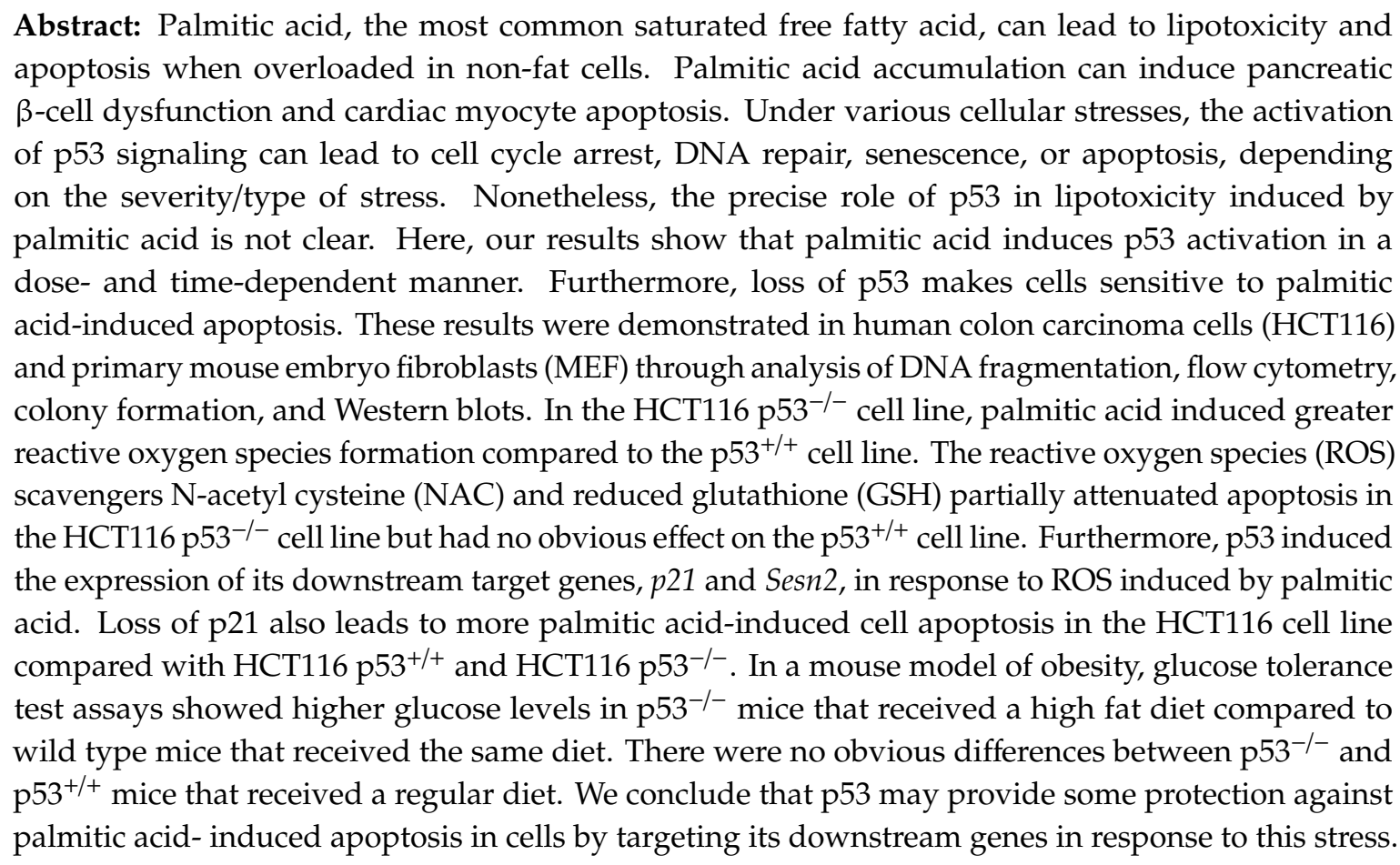
Keywords: palmitic acid; p53; reactive oxygen species; cell apoptosis 


\section{Introduction}

Palmitic acid, a long chain saturated fatty acid, is widely distributed in plants, including palm fruit [1,2], maize grain [3], and other cereal seeds [4,5]. In animals and humans, overloading of palmitic acid in non-fat tissues leads to lipotoxicity and diseases [6,7]. There is increasing evidence that palmitic acid induces cellular apoptosis in Chinese hamster ovary (CHO) cells $[1,8,9]$, pancreatic $\beta$-cells $[10,11]$, breast cancer cell lines [12], cardiac myocytes [13], vascular smooth muscle cell [14], hepatic cells [15], and neural stem cells [16]. The main pathways involved in apoptosis signaling mediated by palmitic acid are generation of reactive oxygen species [1], de novo ceramide synthesis [17], generation of nitric oxide [18], decreases in phosphatidylinositol-3-kinase [12], toll like receptor 4/reactive oxygen species (ROS)/p53 pathway [14], and modification of mitochondrial structure or function [19]. Despite many advances, the precise mechanisms have not been established and vary amongst cell types.

p53 is a multi-functional protein that plays many roles in determining cell fate in response to cellular stress [20-22]. Under severe stress, p53 is activated to induce cell cycle arrest, DNA repair, senescence, or apoptosis, which have been previously shown to contribute to tumor suppression [22,23]. Under stress-free or low stress conditions, p53 increases transcription of multiple downstream target genes (i.e., $p 21, B c L 2$, Sesn1, and Sesn2), engaging anti-apoptosis pathways by counteracting apoptosis in cells [22-26].

In this study, we investigated the role of p53 in lipotoxicity mediated by palmitic acid. Following palmitic acid treatment, apoptosis occurred in both human colon carcinoma (HCT116) cells and primary mouse embryo fibroblast (MEF) cells. Interestingly, palmitic acid induced apoptosis to a greater extent

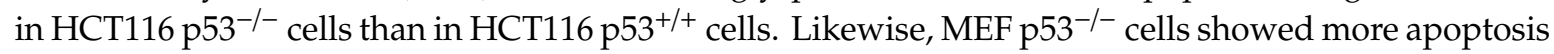
than MEF $\mathrm{p}^{+/++}$cells. An increase in p53 expression was observed following treatment with palmitic acid in $\mathrm{p}^{+/+}$cell lines. DNA laddering was used as an apoptosis marker [27]. More DNA laddering was observed $48 \mathrm{~h}$ after palmitic acid treatment in HCT116 p53 ${ }^{-/-}$cells than in HCT116 p53 ${ }^{+/+}$cells. Quantitative analysis of sub-G1 cells by flow cytometry $[28,29]$ showed significantly more apoptosis

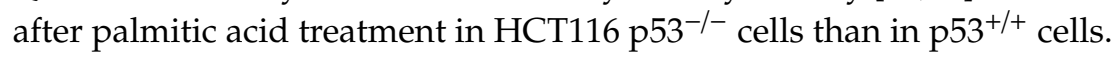

To investigate the response to palmitic acid in normal cells under physiological conditions, primary MEFs were isolated and treated with palmitic acid. Primary MEF $\mathrm{p} 53^{-/-}$cells were sensitive to palmitic acid, like the HCT116 cell lines, and flow cytometry data showed that a substantial number of these cells became apoptotic following palmitic acid treatment. Similar results were observed for palmitic acid-treated MEF $\mathrm{p}^{-/-}$cells in the DNA laddering assay and an Annexin-V staining assay. Previous reports have shown that palmitic acid induces the formation of ROS and that is the main mechanism by which palmitic acid leads to apoptosis [3]. Therefore, ROS levels were measured in HCT116 cells and primary MEF cells. After palmitic acid treatment, ROS levels significantly increased in $\mathrm{p}^{-1} 3^{-/}$cell lines compared to $\mathrm{p}^{+/+}$cell lines. Under these conditions, p53 may therefore function as a scavenger of the ROS induced by palmitic acid. Realtime PCR showed that the downstream target genes $p 21$ and Sesn 2 were significantly induced by palmitic acid. Loss of p21 leads to more cellular apoptosis compared with wide type in the HCT116 cell line under PA stress. To gain insight into palmitic acid's physiological effects, we constructed an animal model of obesity by feeding a high fat diet containing PA to $\mathrm{p} 53^{+/+}$and $\mathrm{p} 53^{-/-}$mice. Among mice receiving the high fat diet, glucose tolerance test assays showed higher glucose levels in $\mathrm{p} 53^{-/-}$mice than wild type mice; there were no differences between $\mathrm{p} 53^{+/+}$and $\mathrm{p} 53^{-/-}$mice that received the regular diet. In summary, p53 may protect cells against lipotoxicity through downstream target genes by eliminating palmitic acid-induced ROS production.

\section{Results}

\subsection{Palmitic Acid Activates $p 53$ in a Dose-and Time-Dependent Manner}

Palmitic acid is a saturated free fatty acid that builds up in non-adipose cells, leading to cell liopotoxicity effects such as apoptosis and disease onset [30]. For example, palmitic acid can induce pancreatic $\beta$-cell dysfunction, resulting in insulin resistance and diabetes $[6,30,31]$, and cardiac myocyte 
apoptosis, leading to heart failure [13,32]. p53 is a tumor suppressor, which is often viewed as a cellular guardian that protects cells from damage [33,34]. In order to investigate p53's role in palmitic acid-induced lipotoxicity, a complex of palmitic acid and albumin with defined ratio was used to mimic saturated free fatty acids under physiological conditions. Although the normal physiological ratio of fatty acid to albumin is about $2: 1$, a ratio of $8: 1$ palmitic acid:bovine serum albumin (BSA) complex (hereafter abbreviated as PA) was used in this experimental system [1]. HCT116 p53 $3^{+/+}$and

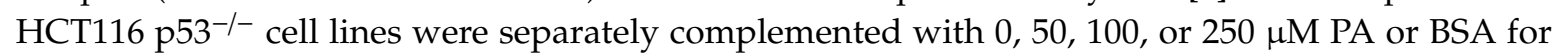

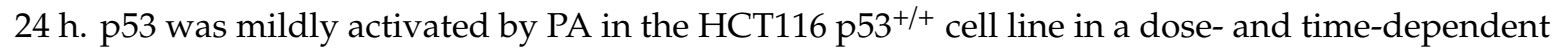
manner (Figure 1A,C). Expression levels of the important p53 target gene, $p 21$ (cyclin-dependent kinase inhibitor 1), also increased significantly after PA treatment (Figure 1A,C). Levels of p21 protein increased by approximately 2-fold relative to the BSA control in HCT116 p53 $3^{+/+}$cells (Figure 1B,D). Interestingly, oleic acid complexed with BSA in an 8:1 ratio (hereafter abbreviated as OA) did not activate p53 as PA did (Figure 1E,F). These results demonstrate that p53 was specifically induced by PA. Palmitic acid activates p53 in a dose- and time-dependent manner and may play an important role in lipotoxicity induced by PA.
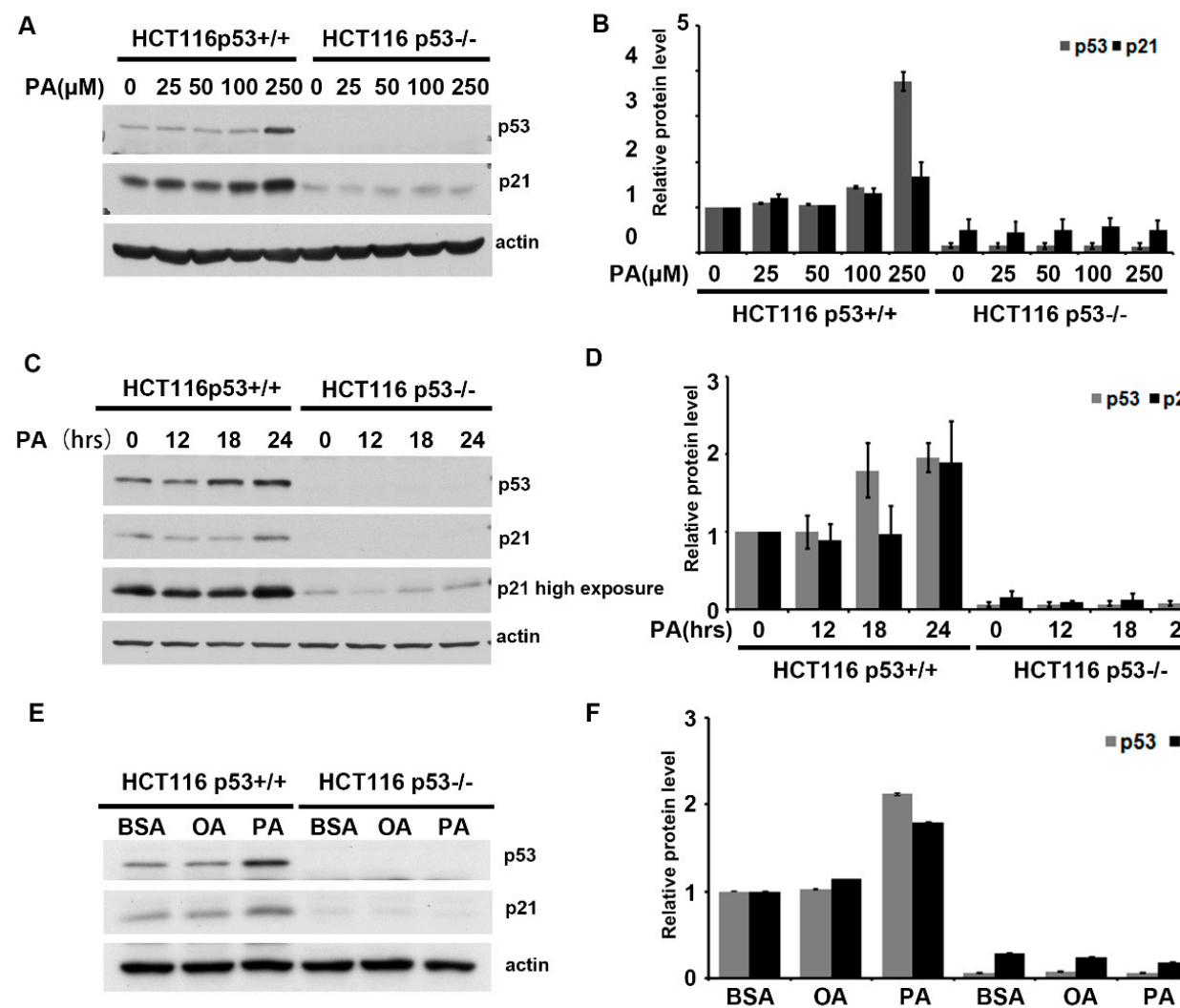

D

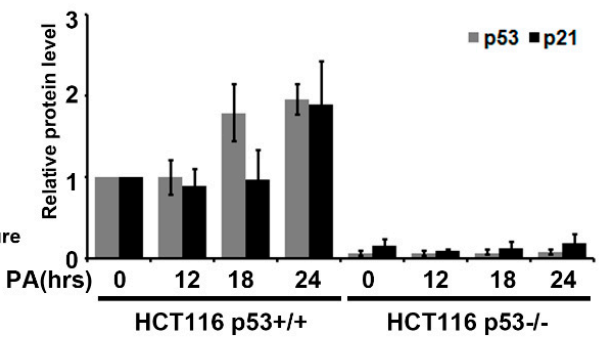

$\mathbf{F}$

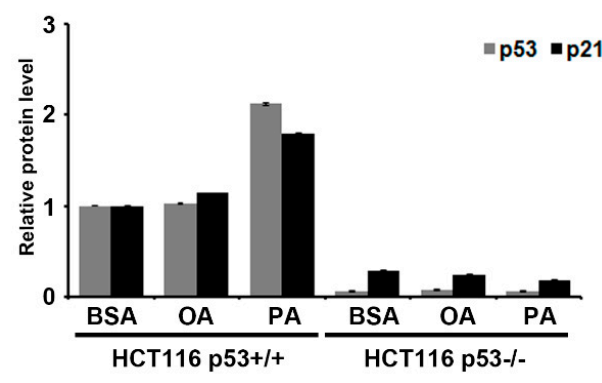

Figure 1. Palmitic acid induces p53 expression in human colon carcinoma cells (HCT116) in a dose- and time-dependent manner. (A) HCT116 $\mathrm{p}^{+/+}$and $\mathrm{p}^{+/-}$cell lines were treated with the indicated dose of palmitic acid. A total of $40 \mu \mathrm{g}$ of total protein extract was resolved on SDS-PAGE. Immunoblotting was performed using p53 and p21 antibodies, and $\beta$-actin was used as a loading control. (B) Quantitative analysis of (A) by ImageJ software. (C) HCT116 cells were treated with $250 \mu \mathrm{M}$ palmitic acid at indicated time points; $40 \mu \mathrm{g}$ of total protein extract was resolved on SDS-PAGE. Immunoblotting was performed using p53 and p21 antibodies, and $\beta$-actin was used as a loading control. (D) Quantitative analysis of (C) by ImageJ software. (E) Palmitic acid, not oleic acid, specifically activated p53 expression. HCT116 cells were treated with $250 \mu \mathrm{M}$ oleic acid and $250 \mu \mathrm{M}$ palmitic acid for $24 \mathrm{~h}$. Immunoblotting was performed using p53 and p21 antibodies. (F) Quantitative analysis of E by ImageJ software. The data are expressed as mean \pm SE of three independent experiments. 


\subsection{Cells are more Sensitive to PA in HCT116 $p 53^{-/-}$Cell Line Compared to HCT116 $p 53^{+/+}$Cell Line}

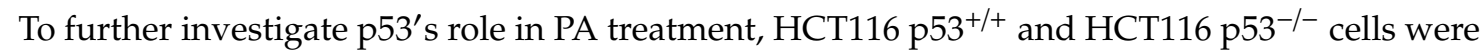
treated with different PA doses and incubated with PA for various time periods. First, we observed that HCT116 ${\mathrm{p} 53^{-/}}^{-}$cells became rounder and gradually broke away from the plate faster than HCT116 $\mathrm{p} 53^{+/+}$cells. To further observe the long-term effects of PA treatment, we seeded HCT116 p53 $3^{+/+}$ and p53-/- cells into 6-well plates at $\left(4 \times 10^{4}\right) 5 \%$ confluence. After $24 \mathrm{~h}$, we separately treated cells with $250 \mu \mathrm{M}$ PA or $250 \mu \mathrm{M}$ OA for $48 \mathrm{~h}$ in the wells. Crystal violet staining was then performed to visualize all cells that remained adherent to the plate under these conditions. PA treatment clearly resulted in a decrease in cell number per plate, which could reflect proliferation arrest and apoptosis, while OA treatment was ineffective (Figure 2A). To verify whether the PA effect was associated with apoptosis, we collected and extracted genomic DNA from the cells that were treated with $250 \mu \mathrm{M} \mathrm{PA}$ for $0-48 \mathrm{~h}$. As an apoptotic cell marker, DNA laddering was observed in the gel (Figure 2B). We also extracted small fragments of apoptotic DNA, like previous results, more cell apoptosis occurred in

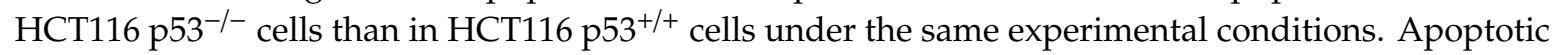
cell was also dependent on PA treatment time (Figure S1). To quantify apoptotic cell, Sub-G1 cells were measured using flow cytometry after propidium iodide staining. After $48 \mathrm{~h}$ of PA treatment, the amount of apoptosis in HCT116 p53 $^{-/-}$cells was more than 2-fold greater than that in HCT116 p53 $3^{+/+}$cells (15.5\% vs. 31.1\%) (Figure 2C,D). These results show that p53 may be required for cell survival under PA treatment and that knocking out of p53 leads to more apoptosis in the HCT116 cell line.

A

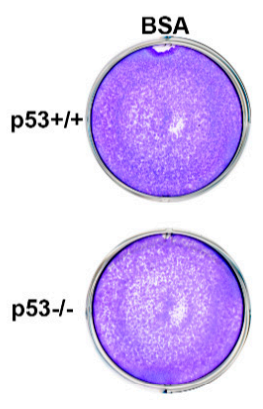

c

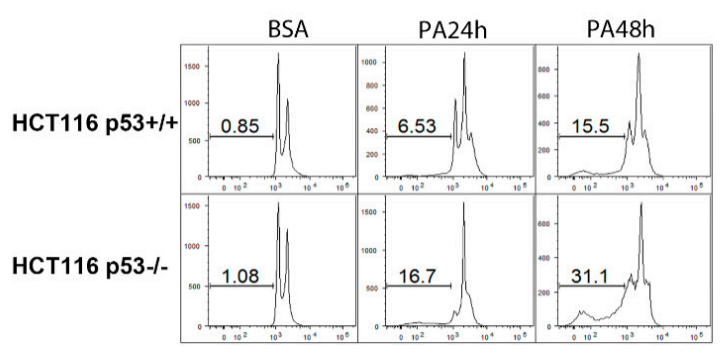

B
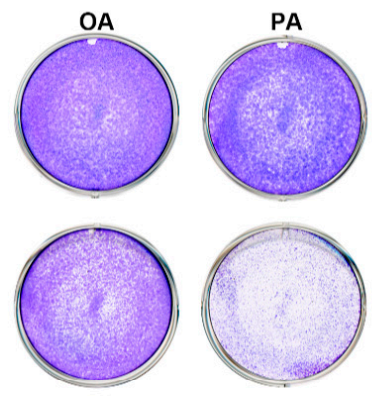

D
HCT116 p53+/t $\mathrm{HCT116}$ p53-/-

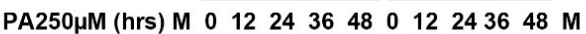
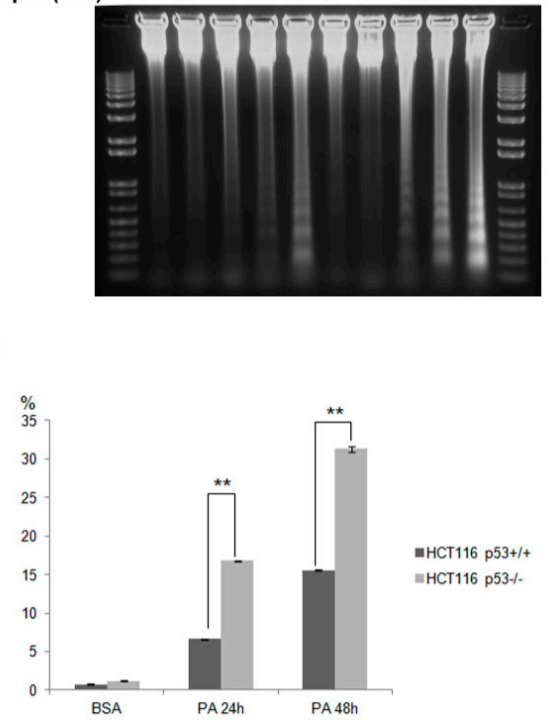

Figure 2. Distinct apoptosis effects induced by palmitic acid in HCT116 p53 ${ }^{+/+}$and p53-/- cell lines. (A) HCT116 cells were treated with $250 \mu \mathrm{M}$ oleic acid or $250 \mu \mathrm{M}$ palmitic acid for $24 \mathrm{~h}$. Crystal violet staining was performed to show all cells (blue) in the plate. (B) After $24 \mathrm{~h}$, HCT116 p53 ${ }^{+/+}$and p53-/cells were treated with $250 \mu \mathrm{M}$ palmitic acid for the indicated times. Cells were harvested, and genomic DNA was extracted. A total of $5 \mu \mathrm{g}$ of DNA was loaded for each sample on a $1 \%$ agarose gel to detect DNA laddering. (C) Apoptotic cells (Sub-G1) were quantified by flow cytometry analysis after treating with $500 \mu \mathrm{M}$ palmitic acid for the indicated time. Cells were stained with $2 \mu \mathrm{g} / \mathrm{mL}$ propidium iodide. DNA content analysis was performed. Values indicate the percentage of sub-G1 cells. (D) Percentages of apoptotic cells were quantified as the mean \pm SE of three independent experiments. Asterisks represent significant differences between HCT116 $\mathrm{p}^{+/+}$and $\mathrm{p}^{-/-}(p<0.01)$ at indicated PA treatment time points. 
2.3. Distinct PA-Induced Apoptosis Effects in $p 53^{+/+}$and $p 53^{-/-}$Primary Mouse Embryo Fibroblast Cell Lines

To examine the physiological significance of p53 in the PA response of non-tumor cells, we isolated primary mouse fibroblasts from 13.5 days $\mathrm{p} 53^{+/+}$and $\mathrm{p} 53^{-/-}$mouse embryos. Primary MEF $\mathrm{p} 53^{+/+}$ and MEF p53-/- were treated with $250 \mu \mathrm{M}$ PA for different time periods (0-48 h). Genomic DNA was extracted from cells, and $5 \mu \mathrm{g}$ of DNA was separated by electrophoresis through $1 \%$ agarose gel (Figure 3A). The DNA laddering assay showed that PA induced significant apoptosis in MEF p53-/- cells but only minimal apoptosis in MEF p53 $3^{+/+}$cells. Furthermore, the molecular apoptosis markers, cleaved PARP and cleaved caspase-3, were both detected by immunoblotting following PA treatment (Figure 3B). Both were significantly increased in MEF $\mathrm{p}^{-/-}$cells relative to MEF $\mathrm{p}^{-1 /+}$ cells and p53 was slightly activated after $24 \mathrm{~h}$ of PA treatment (Figure 3B and Figure S2). This result demonstrates that slightly activated p53 is enough to at least partly inhibit PA-induced apoptosis in MEF cells. Similarly, Sub-G1 cells were measured by flow cytometry after staining with propidium iodide. After $48 \mathrm{~h}$ of PA treatment, PA-induced cell apoptosis rose from $1.18 \%$ to $13.7 \%$ in $\mathrm{MEF} \mathrm{p}^{+/ /+}$ and from $2.43 \%$ to $43.5 \%$ in MEF p53-- (Figure 3C).

Phosphatidylserine is translocated from the inner to the outer leaflet of the plasma membrane in the earliest stages of apoptosis and annexin $\mathrm{V}$ binding to phosphatidylserine is a strong and specific signal for this early apoptotic event $[35,36]$. We performed an annexin binding essay on MEF cells after $24 \mathrm{~h}$ of PA treatment. The results showed more MEF $\mathrm{p}^{-/-}$cells entering apoptosis than MEF $\mathrm{p} 53^{+/+}$ cells (Figure 3D). Like the results seen in HCT116 cells, these results demonstrate that even mildly activated p53 may be enough to at least delay or repair cell damage induced by PA treatment and thus avoid cell apoptosis.

A

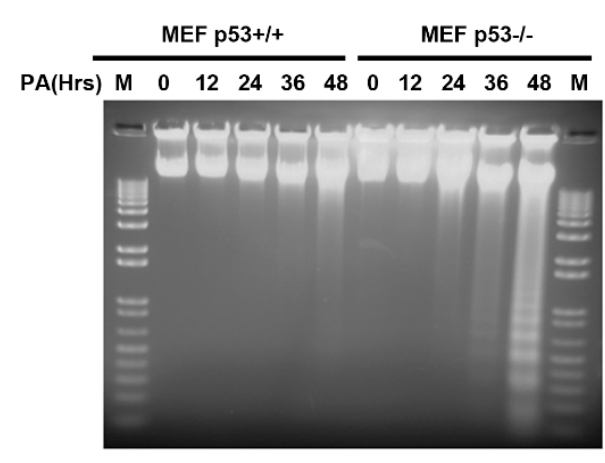

B

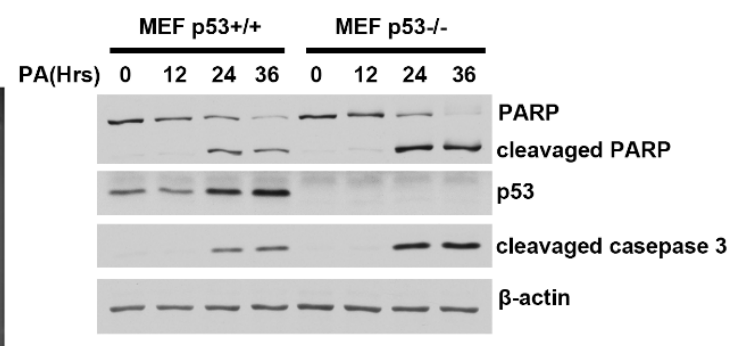

Figure 3. Cont. 
c

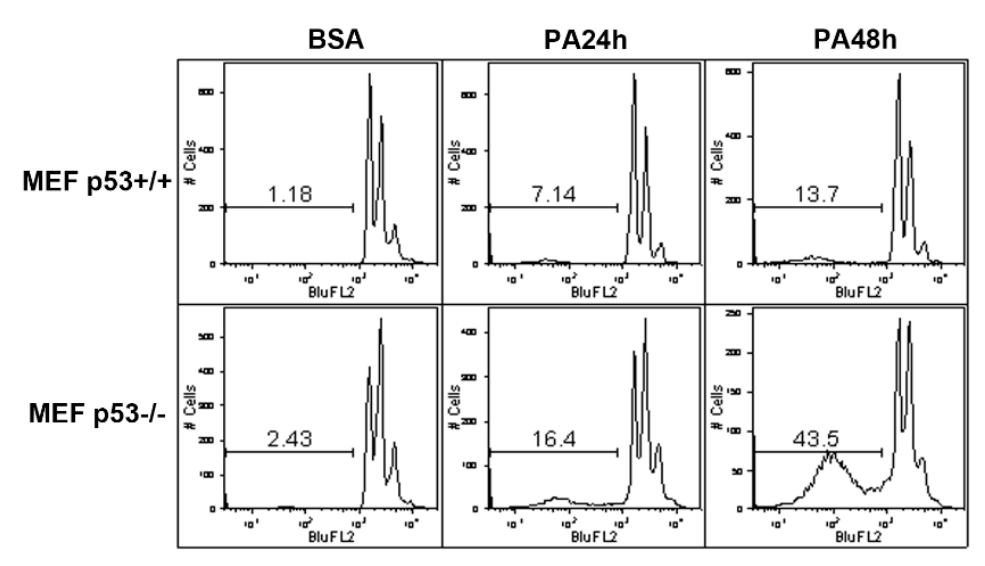

D

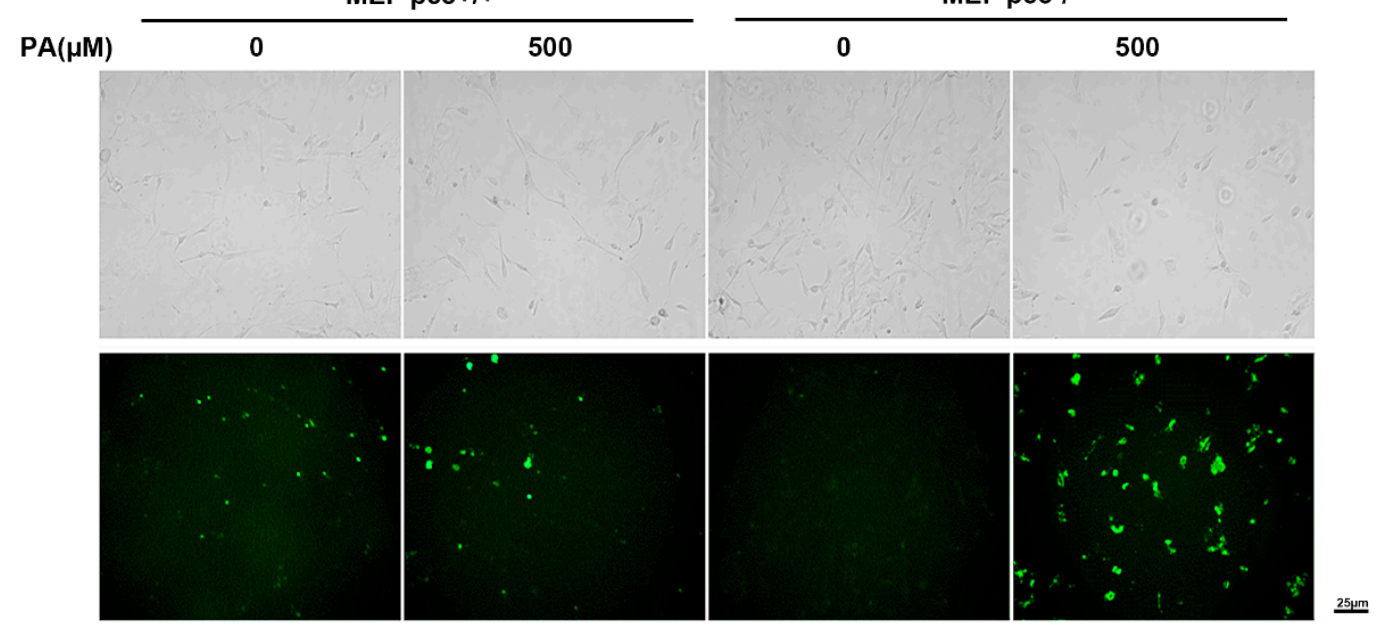

Figure 3. Distinct PA-induced apoptosis effects in mouse embryo fibroblasts (MEF) p53 ${ }^{+/+}$and p53-/cell lines. (A) Primary MEF cells were treated with palmitic acid for the indicated time periods (0-48 h). Genomic DNA was isolated from primary MEF after treatment with palmitic acid. A total of $5 \mu \mathrm{g}$ of DNA was loaded for each sample on a 1\% agarose gel to detect DNA laddering. (B) Primary MEF cells were treated with palmitic acid for the indicated time. A total of $40 \mu \mathrm{g}$ of total protein extract was resolved on SDS-PAGE. p53, cleaved caspase-3, PARP, and cleaved PARP were detected by Western blotting. $\beta$-actin was used as a loading control. (C) FACS analysis of primary MEF $\mathrm{p} 53^{+/+}$and $\mathrm{p} 53^{-/-}$ cells treated with palmitic acid for the indicated time. Cells were fixed with cold methanol, stained with propidium iodide, and subjected to DNA content analysis by flow cytometry. (D) Primary MEF p53-/cells showed greater apoptosis than primary MEF $553^{+/+}$cells following $24 \mathrm{~h}$ of palmitic acid treatment, visualized by staining with Annexin V-FITC for $15 \mathrm{~min}$ at RT. An Advanced Microscopy Group (AMG) Evos $\mathrm{f} 1$ microscope was used for imaging. The scale is $25 \mu \mathrm{m}$.

\subsection{ROS Contributes at Least Partly to the Cell Apoptosis Induced by PA}

Accumulation of ROS in cells treated with PA is known to be a contributing factor in PA-induced lipotoxicity [37-40]. Therefore, we used $\mathrm{H}_{2}$ DCFDA to test whether p53-mediated anti-apoptosis was associated with a decrease in ROS. DCFDA diffuses into cells, where it is deacetylated to DCF, which in turn fluoresces upon reaction with a variety of ROS [41]. ROS was measured in HCT116 p53-/- and p53 $3^{+/+}$cells treated with 250 or $500 \mu \mathrm{M}$ PA for $24 \mathrm{~h}$. As Figure 4A,B shows, ROS accumulated more in HCT116 p53 ${ }^{-/-}$cells than in HCT116 p53 ${ }^{+/+}$cells. ROS increased almost 4-fold compared with BSA controls in HCT116 p53 $^{-/-}$cells from the PA500 treatment group; however, ROS increased only 2-fold compared with BSA controls in HCT116 p53 $3^{+/+}$cells from the same treatment group (Figure 4A,B). Similarly, we measured ROS levels in MEF cells treated with PA500; ROS increased 2-fold in MEF p53-/- cells but increased only slightly in MEF p53 ${ }^{+/+}$cells (Figure 4C). Treatment for $24 \mathrm{~h}$ with PA 
and the ROS scavengers N-acetyl-cysteine (NAC) or glutathione (GSH) decreased DNA laddering observed in MEF $\mathrm{p}^{-/-}$cells but not MEF $\mathrm{p} 53^{+/+}$cells, suggesting that NAC and GSH partially reduced PA-induced apoptosis in MEF p53-- cells (Figure 4D). These results showed that ROS play an important role in apoptosis and that HCT116 and MEF cells are at least partly dependent on p53 to eliminate ROS production in response to PA treatment.

A

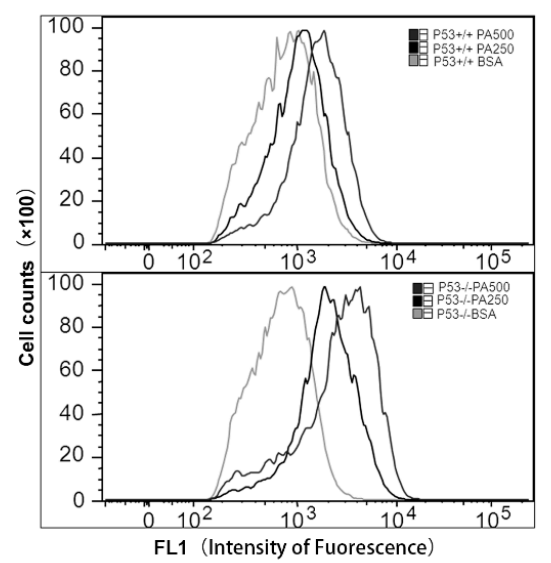

C

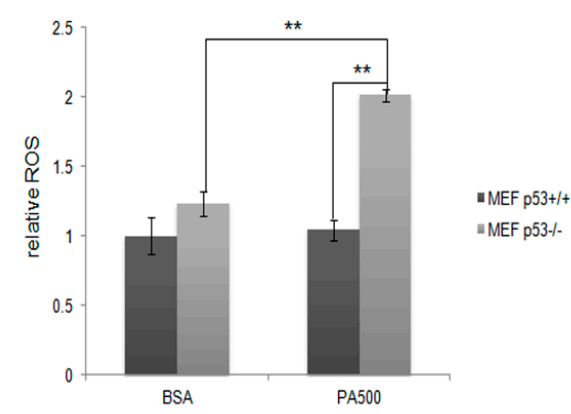

B

D
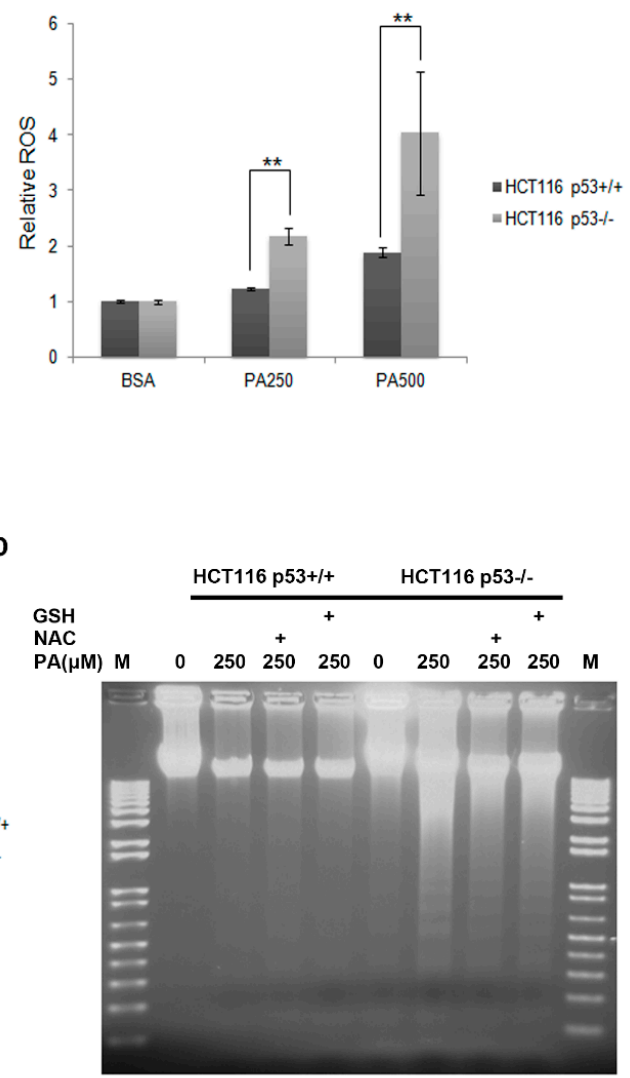

Figure 4. HCT116 $\mathrm{p} 53^{-/-}$cells accumulate more reactive oxygen species (ROS) than $\mathrm{p} 53^{+/+}$cells after palmitic acid treatment. (A) Palmitic acid induces ROS in a dose-dependent manner after $24 \mathrm{~h}$ of treatment. ROS were analyzed by flow cytometry as described in Materials and Methods. HCT116 p53 $3^{+/+}$and p53-/- cells were treated with 0,250 , and $500 \mu \mathrm{M}$ palmitic acid for $24 \mathrm{~h}$. (B) Quantification of ROS induced by palmitic acid in HCT116 $\mathrm{p} 53^{+/+}$and $\mathrm{p} 53^{-/-}$cell lines. The data are expressed as mean \pm SE of three independent experiments $(n=3)$. Asterisks represent significant differences

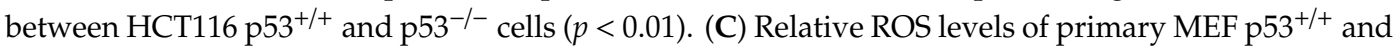
p53-/- cells. The data are expressed as mean \pm SE of three independent experiments $(n=3)$. Asterisks represent significant differences between primary MEF $\mathrm{p}^{+/+}$and $\mathrm{p} 53^{-/-}$cells $(p<0.01)$. (D) A $24 \mathrm{~h}$ treatment with the antioxidants glutathione $(\mathrm{GSH}, 20 \mu \mathrm{g} / \mathrm{mL}$ ) or N-Acetyl cysteine (NAC, $200 \mu \mathrm{g} / \mathrm{mL}$ ) attenuated primary MEF cell apoptosis caused by palmitic acid in MEF p53-1- cells. A total of $5 \mu \mathrm{g}$ of DNA was loaded for each sample on a $1 \%$ agarose gel to detect DNA laddering.

\subsection{Gene Expression Induced by $p 53$ Under PA Stress in HCT116 and MEF Cell Lines.}

To study potential mechanisms of PA stress, we examined the expression of two key genes induced by p53: $p 21$ and Sesn2. p21 expression has been widely investigated in response to different stresses. HCT116 cells and MEF cells were treated with $250 \mu \mathrm{M}$ PA for different time periods. Real-time fluorescence quantitative PCR was performed to measure the expression of $p 21$. $p 21$ expression was induced 2- to 3-fold higher by PA in p53 wild type cells (Figure 5A,C). Sesn2 plays an important role in maintaining redox and metabolic homeostasis, previous studies have reported that Sesn 2 is involved 
in antioxidant processes as a downstream target of p53. We measured the expression of Sesn 2 in response to PA treatment of $\mathrm{p} 53^{+/+}$and $\mathrm{p} 53^{-/-}$cell lines. After $36 \mathrm{~h}$ of PA treatment, Sesn 2 expression increased more than 3-fold in HCT116 $\mathrm{p}^{+/+}$cells but only 2.8 -fold in HCT116 $\mathrm{p}^{-/-}$cells. Similarly, Sesn 2 expression increased more than 2.5-fold in MEF $\mathrm{p} 53^{+/+}$cells but only 1.6-fold in MEF $\mathrm{p} 53^{-/-}$ cells after $36 \mathrm{~h}$ of PA treatment (Figure 5B,D). In order to further investigate the effect of p21 under PA stress, we detected cell apoptosis in the HCT116 p21-/- cell line. The results indicate that loss of p21 is

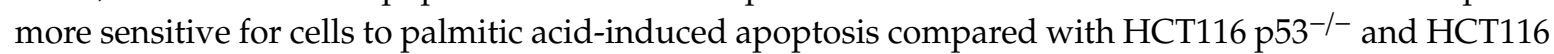
$\mathrm{p} 53^{+/+}$(Figure 5E). These results show that p53 may play a protective role in PA stress through the expression of its target genes.

A

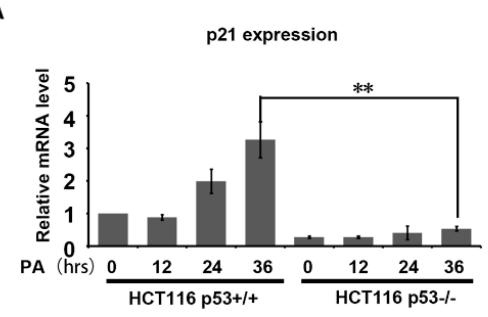

C

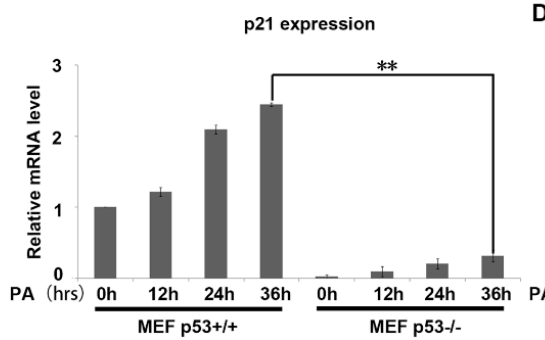

B

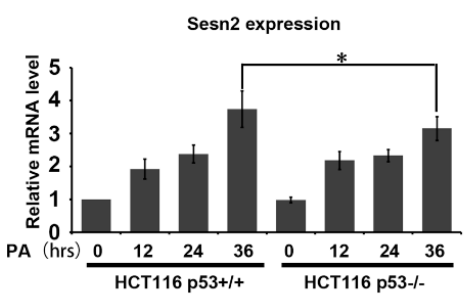

D

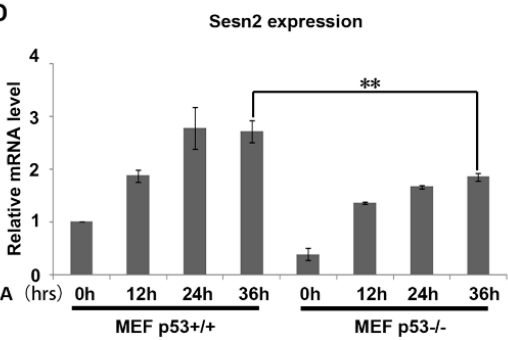

E

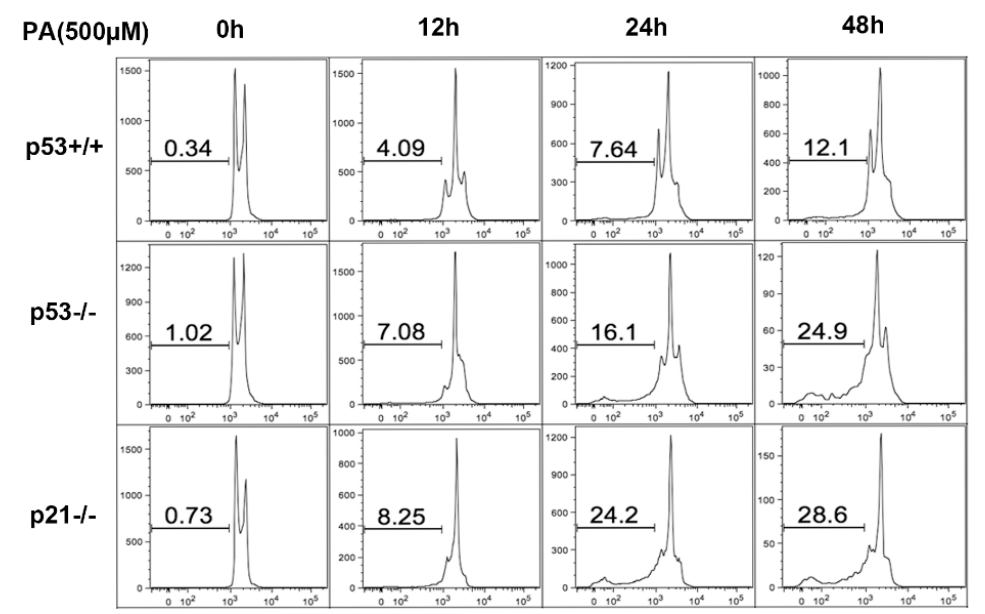

Figure 5. Expression of $p 21$ and Sesn 2 genes in $\mathrm{p} 53^{+/+}$and $\mathrm{p} 53^{-/-}$cells under PA stress. (A) Relative mRNA expression of $p 21$ under $250 \mu \mathrm{M}$ PA stress at indicated time points in HCT116 p53 $3^{+/+}$and p53 $3^{-/-}$ cell lines. ${ }^{* *}$ indicates $p<0.01, n=6$. (B) Relative mRNA expression of Sesn2 under $250 \mu \mathrm{M}$ PA stress at

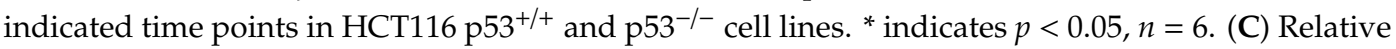
mRNA expression of $p 21$ under $250 \mu \mathrm{M}$ PA stress at indicated time points in MEF p53 $3^{+/+}$and p53-/cell lines. ${ }^{* *}$ indicates $p<0.01, n=6$. (D) Relative mRNA expression of Ses 2 under $250 \mu \mathrm{M}$ PA stress at indicated time points in MEF $\mathrm{p} 53^{+/+}$and $\mathrm{p} 53^{-/-}$cell lines. ${ }^{* *}$ indicates $p<0.01, n=6$. (E) Apoptotic cells (Sub-G1) were quantified by flow cytometry analysis after treating with $500 \mu \mathrm{M}$ palmitic acid for the indicated time in HCT116 p53 ${ }^{+/+}, \mathrm{HCT} 116 \mathrm{p} 53^{-/-}$, and p53 p21 $1^{-/-}$cell lines. Cells were stained with $2 \mu \mathrm{g} / \mathrm{mL}$ propidium iodide. DNA content analysis was performed. Values indicate the percentage of sub-G1 cells. 


\subsection{Biological Effect on Mice in PA Stress}

Previous investigations have reported that palmitic acid induces pancreatic $\beta$-cell dysfunction, resulting in insulin resistance and diabetes. To further study the potential biological significance of p53 in PA stress, we chose approximately three-week-old littermates of $\mathrm{p} 53^{+/+}$and $\mathrm{p} 53^{-/-}$mice to receive high fat food or regular food for 52 days, followed by performance of glucose tolerance test assays. After 52 days, $\mathrm{p} 53^{+/+}$mice that received the high fat diet had increased from 18.55 to 44.03 $\mathrm{g}$ in weight, and $\mathrm{p} 53^{-/-}$mice that received the high fat diet had increased from 16.49 to $40.79 \mathrm{~g}$. On the other hand, $\mathrm{p} 53^{+/+}$mice that received regular food increased from 16.59 to $29.21 \mathrm{~g}$, and $\mathrm{p} 53^{-/-}$ mice that received regular food increased from 15.85 to $27.75 \mathrm{~g}$. These results show that the body weights of $\mathrm{p} 53^{+/+}$mice and $\mathrm{p} 53^{-/-}$mice increased to different extents. $\mathrm{p} 53^{-/-}$high fat diet mice were significantly heavier compared with $\mathrm{p} 53^{-/-}$regular food mice and $\mathrm{p} 53^{+/+}$high fat diet mice were significantly heavier compared with $\mathrm{p}^{+/+}$regular food mice. Clearly the high fat diet leads to obesity and the model of obesity was successfully constructed. However, $\mathrm{p} 53^{-/-}$high fat diet mice were not significantly different in body weight from $\mathrm{p} 53^{+/+}$high fat diet mice. Nor were $\mathrm{p} 53^{-/-}$regular food mice

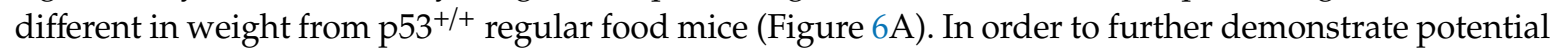
biological significance of p53 in PA stress, an intraperitoneal glucose tolerance assay was performed according to previously reported protocols $[42,43]$. Glucose values were significantly different between $\mathrm{p} 53^{-/-}$high fat diet mice and $\mathrm{p} 53^{+/+}$high fat diet mice $15 \mathrm{~min}$ after injection of glucose. However, there were no differences in glucose values between $\mathrm{p} 53^{-/-}$and $\mathrm{p} 53^{+/+}$regular food mice (Figure $6 \mathrm{~B}$ ). These results indicate that glucose resistance was reduced in $\mathrm{p} 53^{-/-}$high fat diet mice than in $\mathrm{p} 53^{+/+}$ high fat diet mice.

A

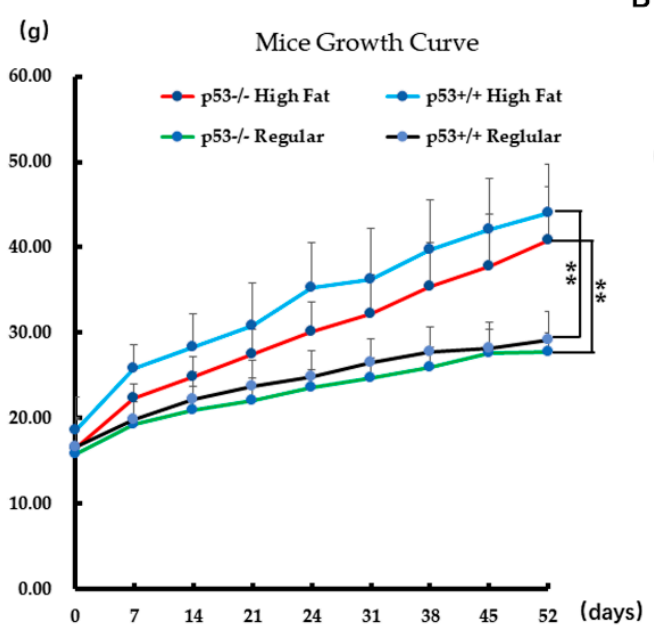

B

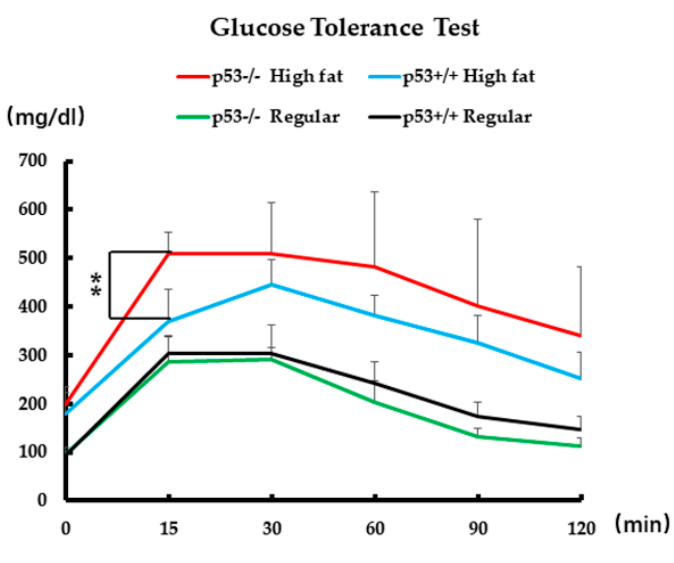

Figure 6. Biological effects of PA stress on mice feed a high fat diet. (A) Growth curves of mouse weight under a high fat diet and a regular diet. ${ }^{* *}$ indicates $p<0.01, n=5$. (B) Glucose tolerance test results at indicated time points after glucose injection. ${ }^{* *}$ indicates $p<0.01, n \geq 3$.

\section{Discussion}

Activation of p53 signaling under stressful conditions is widely accepted to mediate suppression of tumor growth by triggering senescence or apoptosis, depending on the type/amount of stress as well as the genetic background of the cells [44-46]. Interestingly, it was reported when p53's ability to induce apoptosis, cell cycle arrest, and senescence was blocked, it was still able to suppress tumor formation [47]. Therefore, p53's other functions, such as suppression of glucose uptake and regulation of glycolysis and ROS, are also important for inhibition of tumor formation [48,49]. More and more evidence has been proposed that p53 regulates a large number of genes involved in cell metabolism, such as PTEN, TIGAR, SCO2, GAMT, SCO2, and Lpin1 [23]. In addition, there is increasing evidence that p53 can also function to prevent apoptosis [50-52]. The level of p53 expression is the key factor 
in determining cell fate [52]. In our current research, we found that low or normal levels of p53 had an anti-apoptotic and pro-survival effect in response to palmitic acid. When we knocked down the expression of $p 53$ by siRNA and treated these cells with PA, we could not detect increased apoptosis relative to wild type. When we over-expressed $p 53$ in HCT116 cell lines even without PA, we detected more cell apoptosis compared to cells expressing normal $p 53$ level. Therefore, base level or low level of p53 is important for apoptosis induced by PA.

It has already been shown that several cell types undergo apoptosis in response to palmitic acid treatment, including pancreatic $\beta$-cells [10,11], breast cancer cell lines [12], cardiac myocytes [13], vascular smooth muscle cells [14], hepatic cells [15], and neural stem cells [16]. These apoptotic systems are associated with various diseases. For example, pancreatic $\beta$-cell dysfunction leads to insulin secretion resistance which in turn causes hyperglycemia and diabetes. Likewise, apoptosis of cardiac myocytes results in heart failure. Here, more apoptosis occurred in MEF $\mathrm{p}^{-1-}$ cells compared with MEF $\mathrm{p}^{+/++}$cells, which is important because the absence of p53 may contribute to various apoptosis-related diseases. Our results suggest that $\mathrm{p} 53$ can potentially promote cell survival under PA treatment. Consistent with the known functions of p53, p53 protects cells against DNA damage under low-level cellular stress in normal cells [34].

Accumulation of ROS in cells treated with PA has been shown to be a contributing factor in PA-induced apoptosis [1]. Increasing evidence shows that p53 regulates ROS through various pathways in vivo and in vitro [53]. p53 generates ROS under high cellular stress conditions and after severe cellular damage inducing apoptosis [51]. Interestingly, under normal or low stress states, p53 can also promote cell survival through p21 induction of cell cycle arrest and recruitment of DNA repair factors such as p53R2 [54] and GADD45 [55]. In a previous report, the expression of GADD45 in the HepG2 cell line increased following treatment with PA [56]. In our current research, p53 was mildly activated in a dose- and time-dependent manner in the HCT116 cell line following PA treatment. p53 was activated potentially to promote GADD45 expression, echoing research in HepG2. The apoptosis response of

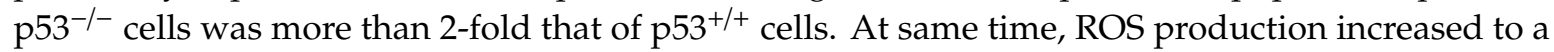

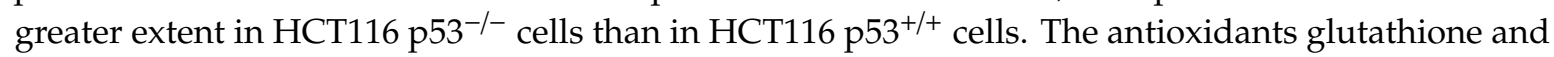
$\mathrm{N}$-Acetyl cysteine at least partly attenuated apoptosis caused by palmitic acid in HCT116 $\mathrm{p} 53^{-/-}$cells

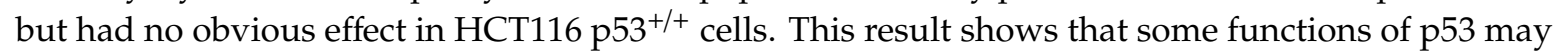
have antioxidant effects. As a downstream target of p53, the antioxidant-related gene Sesn 2 increased

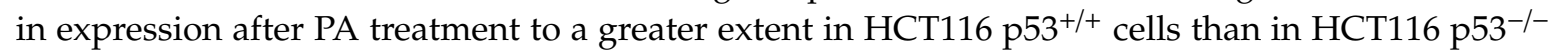
cells. It partly abolished ROS in HCT116 p53 $3^{+/}$cells but had no obvious effect in HCT116 p53-/- cells. Therefore, the potential mechanism by which p53 protects cells from apoptosis is by inducing Sesn 2 gene expression, partially ameliorating ROS damage to cells after PA treatment.

As an important p53 response gene, $p 21$ encodes an inhibitor of cyclin-dependent kinases [40], whose expression is sensitive to even low levels of p53 activation. The expression of $p 21$ leads to cell cycle arrest at G1 or G2, which temporarily allows cells to survive until damage has been repaired or cellular stress resolved [57]. We compared the expression of $p 21$ in HCT116 p53 ${ }^{+/+}$and HCT116 p53-/cells under PA treatment. Although p53 was moderately induced by PA treatment, the expression of p 21 in HCT116 p53 $3^{+/+}$cells was more than 3 -fold than in HCT116 p53 $3^{-/-}$cells after $36 \mathrm{~h}$ of PA treatment. The level of ROS was also significantly higher in HCT116 p53-/- cells compared to HCT116 p53 $3^{+/+}$ cells. Furthermore, more apoptosis occurs in HCT116 p21 $1^{-/-}$cells compared with HCT116 p53 $3^{-/}$and

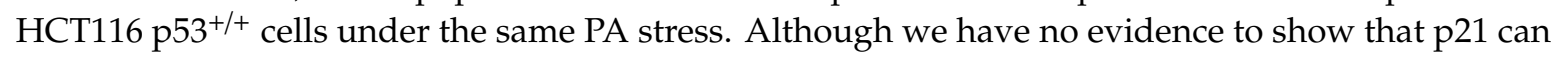
directly reduce ROS levels, our data show that more apoptosis was detected in cell lines that also exhibited relatively low p21 levels. This observation is consistent with multifunctional property of p21, which includes its ability to suppress apoptosis by acting at different levels of the death cascade, and to promote growth arrest through senescence $[44,58]$. Therefore, cell cycle arrest was induced by $\mathrm{p} 21$, which at least partly contributed to p53-mediated survival under PA stress. In the current work we used standard molecular and cellular features of apoptosis. However, it is now well known that cells triggered to undergo apoptosis can recover from brink of death through a process called 
anastasis [59]. Therefore, to what extent the responses reported herein reflect death remains to be determined. In addition, glutathione and N-Acetyl cysteine could not completely abolish apoptosis under PA treatment in both HCT116 and primary MEF cell lines. There may be other mechanisms by which p53 contributes to cell apoptosis protection in response to PA treatment.

Physiologically, p53 appears to act as cell protector in vivo under PA stress. In our mouse model of obesity, we observed higher glucose level in $\mathrm{p} 53^{-/-}$mice that received a high fat diet than in $\mathrm{p} 53^{+/+}$ mice that received the same diet. Although we did not directly measure $\beta$-cell dysfunction in vivo, we hypothesize that $\beta$-cell apoptosis occurs to a greater extent in $\mathrm{p} 53^{-/-}$mice than in $\mathrm{p} 53^{+/+}$mice under PA stress. Overall, this research highlighted differences in the apoptotic effect induced by PA in $\mathrm{p}^{2} 3^{+/+}$ and $\mathrm{p} 53^{-/-}$cell lines. Our results suggest that p53 can potentially protect cells from apoptosis induced by PA treatment.

\section{Materials and Methods}

\subsection{Materials}

Palmitic acid, oleic acid, and N-Acetyl cysteine (NAC) were purchased from Fisher Scientific. Fatty acid-free bovine serum albumin (BSA), propidium iodide (PI), and glutathione were purchased from Sigma. 5-(and-6)-chloromethyl-2',7-dichlorodihydrofluorescein diacetate and acetyl ester (Cat: C6827) were purchased from Invitrogen. The Annexin V-FITC Fluorescence Microscopy kit (Cat: 556547) was obtained from BD Pharmingen.

\subsection{Preparation of Albumin-Bound Fatty Acid}

We dissolved $0.046 \mathrm{~g}$ palmitic acid in $0.01 \mathrm{M} \mathrm{NaOH}$, for a total volume of $15 \mathrm{~mL}$, by stirring at $70{ }^{\circ} \mathrm{C}$ for $30 \mathrm{~min}$. Dropwise addition of $1 \mathrm{~N} \mathrm{NaOH}$ facilitated solubilization of the palmitic acid. It was immediately added to $2 \times$ PBS albumin solution dropwise over $30-40 \mathrm{~s}$ while stirring. When the palmitic acid solution became clear, the solution was adjusted with $0.1 \mathrm{~N} \mathrm{HCl}$ to $\mathrm{pH}$ 7.4. The resulting solution had an 8:1 molar ratio of palmitic acid to BSA. Albumin-bound palmitic acid solution (palmitic acid) was diluted 12-fold in cell culture medium. An albumin-bound oleic acid solution was also prepared as above; $6 \mathrm{mM}$ oleic acid was used as stock solution. We dissolved $56.7 \mu \mathrm{L}$ of pure oleic acid in $15 \mathrm{~mL}$ PBS; the clear solution was immediately added to the PBS albumin solution dropwise over 30-40 s while stirring. These methods were adapted from Spector's Protocol [60].

\subsection{Cell Culture and Isolation of Mouse Embryonic Fibroblasts}

HCT116 cell lines were from Bert Vogelstein lab and cultured in McCoy's 5A medium (Cellgro) supplemented with $10 \%$ FBS, 50 units/mL penicillin, and 50 units/mL streptomycin. Primary mouse embryonic fibroblasts were isolated from embryos of $\mathrm{p} 53^{+/-}$mice at 13.5 days post fertilization and cultured in Dulbecco's modified Eagle's medium supplemented with 10\% FBS, 50 units/mL penicillin, and 50 units/mL streptomycin. For palmitic/oleic acid treatment, cell culture medium was supplemented with palmitic acid or oleic acid both complexed with BSA at an 8:1 molar ratio. All cells were cultured in a humidified atmosphere of $5 \% \mathrm{CO}_{2}$ at $37^{\circ} \mathrm{C}$.

\subsection{SDS-PAGE and Immunoblotting}

Cells were washed with cold PBS and lysed in flag lysis buffer (50 mM Tris-Cl pH 7.3, 137 $\mathrm{mM} \mathrm{NaCl}, 10 \mathrm{mM} \mathrm{NaCl}, 10 \%$ glycerol, $0.5 \mathrm{mM}$ EDTA, 1\% Triton X-100, 0.2\% Sarkosyl and fresh protease inhibitor cocktail from Sigma, Cat: P8340). Protein concentration was determined by the Bio-Rad protein assay (Cat: 500-0006). For immunoblotting, proteins were resolved by SDS-PAGE and transferred to Amersham Hybond ECL Nitrocellulose membranes (GE healthcare, Cat: RPN303B), followed by incubation with primary and secondary antibodies and detection with the ECL kit (GE Healthcare, Cat: RPN2109). All Western blot assays were performed independently at least three times. 
The following antibodies were used in this study: p53 (DO-1), p21 (SC-19) from Santa Cruz; caspase-3, PARP from Cell Signaling; and $\beta$-actin from Sigma.

\subsection{Cell Viability Analysis and ANNEXIN V-FITC Staining}

To measure cell apoptosis rates, cells were seeded into 6-well plates at $\left(4 \times 10^{4}\right) 5 \%$ confluence and then incubated with fatty acids for $24 \mathrm{~h}$. After removing the medium, colony staining solution $(0.5 \mathrm{~g}$ crystal violet, $27 \mathrm{~mL} \mathrm{37 \%}$ formaldehyde, $100 \mathrm{~mL} \mathrm{10 \times} \mathrm{PBS,} 10 \mathrm{~mL}$ methanol, $863 \mathrm{~mL} \mathrm{H}_{2} \mathrm{O}$ ) was added to cover the plate. Plates were incubated for $20 \mathrm{~min}$ at room temperature, washed with water, and air dried. Pictures were obtained with an Epson Perfection V700 Photo scanner once the plates had dried. Annexin V-FITC binding was performed according to the recommended protocol. Cells were seeded in 6-well plates, and after $24 \mathrm{~h}$ they were treated with $500 \mathrm{mM}$ palmitic acid for $24 \mathrm{~h}$. The cells were briefly washed twice with $1 \times$ PBS, washed once with $1 \times$ Annexin V binding buffer and then stained with Annexin V-FITC diluted 1:10 in 1× Annexin V binding buffer for $15 \mathrm{~min}$ at RT. After staining, the cells were washed once with $1 \times$ binding buffer; then binding buffer was added for observation and photography with an Advanced Microscopy Group EVOS f1 microscope.

\subsection{Propidium Iodide (PI) Staining and Flow Cytometry.}

Cells were treated with $500 \mu \mathrm{M}$ palmitate. They were then washed with PBS, trypsinized, collected at $0,12,24,36$, and $48 \mathrm{~h}$, and suspended in PBS. Cells were fixed with cold methanol overnight, centrifuged at $3000 \mathrm{rpm}$ for $5 \mathrm{~min}$, spun down, suspended in PBS with $20 \mu \mathrm{g} / \mathrm{mL}$ RNase for $30 \mathrm{~min}$ at $37^{\circ} \mathrm{C}$, stained with $2 \mu \mathrm{g} / \mathrm{mL}$ propidium iodide for $10 \mathrm{~min}$ and analyzed for DNA content by flow cytometry. Cells were treated with $500 \mu \mathrm{M}$ palmitate. They were then washed with PBS, trypsinized, collected at $0,12,24,36$, and $48 \mathrm{~h}$ and suspended in PBS. Cells were fixed with cold methanol overnight, centrifuged at $3000 \mathrm{rpm}$ for $5 \mathrm{~min}$, spun down, suspended in PBS with $20 \mu \mathrm{g} / \mathrm{mL}$ RNase for $30 \mathrm{~min}$ at $37^{\circ} \mathrm{C}$, stained with $2 \mathrm{\mu g} / \mathrm{mL}$ propidium iodide for $10 \mathrm{~min}$ and analyzed for DNA content by flow cytometry.

\subsection{ROS Measurement and DNA Ladder Assay}

To determine ROS levels after supplementation with fatty acids at different time points, HCT116 cells and primary MEF cells were stained for 15 min with fresh $2 \mu \mathrm{M} \mathrm{H}_{2}$ DCFDA (Invitrogen) dissolved in DMSO. Cells were then washed with HBSS buffer and analyzed by flow cytometry. HCT116 cells and primary MEF cells were harvested, including floating cells, at various time points after supplementation with $500 \mu \mathrm{M}$ palmitic acid or $500 \mu \mathrm{M}$ palmitic acid with $200 \mu \mathrm{M}$ N-Acetyl cysteine (NAC) or glutathione. Cells were suspended in $475 \mu \mathrm{L}$ of lysis buffer (10 mM Tris, $\mathrm{pH}$ 8.0, $100 \mathrm{mM} \mathrm{NaCl}, 10 \mathrm{mM}$ EDTA, $0.5 \%$ SDS $)$ with freshly added protease $\mathrm{K}(25 \mu \mathrm{L}$ of $20 \mathrm{mg} / \mathrm{mL})$ and incubated overnight at $50^{\circ} \mathrm{C}$. Then, $5 \mathrm{M} \mathrm{NaCl}$ was added dropwise to give a final concentration of $200 \mathrm{mM}$ and the samples were purified using the genomic DNA isolation protocol for the Manual Phase Lock Gel (PLG) kit (5Prime). Equal quantities $(5 \mu \mathrm{g})$ of each DNA sample were run on 1.0\% agarose gels in TAE buffer ( $40 \mathrm{mM}$ Tris- $\mathrm{Cl} \mathrm{pH}$ 8.0, $20 \mathrm{mM}$ acetic acid, and $1 \mathrm{mM}$ EDTA). Images were collected with a BioDoc-IT Imaging system.

\subsection{Construction of a Model of Mice Obesity and Glucose Resistance Assay}

Mice (C57BL/6J) were maintained in the Animal Core Facility following procedures approved (approval number pro2012426, 10th, April, 2012) by the Animal Care and Use Committee of Albany Medical College. Five littermates of ${\mathrm{p} 53^{-/}}^{-}$and $\mathrm{p} 53^{+/+}$mice were chosen to receive either a high fat diet (Research Diets, Inc., Cat: D12492) or regular food (Research Diets, Inc., Cat: 12450B) after genotyping at 21 days old. Each group contained five $\mathrm{p} 53^{-/-}$or $\mathrm{p} 53^{+/+}$mice that received a high fat diet or a regular diet for 52 days. An intraperitoneal glucose tolerance test (IPGTT, $1 \mathrm{~g}$ glucose/kg body weight) was conducted on fasted mice (for $12 \mathrm{~h}$ ). Glucose levels were measured with the OneTouch Ultra glucometer (Lifescan Benelux, Beerse, Belgium) in 0, 15, 30, 45, 60, 90, and 120 min by tail vein 
puncture. The statistical significance of differences between means was assessed using Student's $t$-test $\left({ }^{* *} p<0.01 ; * p<0.05\right)$. Data were expressed as mean $\pm \mathrm{SE}, n \geq 3$.

\subsection{Real Time PCR and Statistical Analysis}

RNA was extracted from cells using TRIZOL Reagent (Life Technologies, Cat: 15596018) and cDNA was prepared using MMLV reverse transcriptase according to the relevant protocol (NEB, Cat: M0253L). Quantitative real time PCR was performed with Fast SYBR Green QPCR master mix (AB Applied Biosystems, Cat: 4367659) using the following primers: $p 21$ forward: $5^{\prime}$-CCATGT GGACCTGTCACTGTCTT-3' , p21 reverse: 5'-CGGCCTCTTGGAGAAGATCAGCCG-3'; Sesn2 forward: $5^{\prime}$-TCCGCCACTCAGAGAAGTC-3', Sesn 2 reverse: $5^{\prime}$-GTTCAGGAAGGCCACAACAC-3'. The statistical significance of differences between means was assessed using Student's $t$-test $\left({ }^{* *} p<0.01 ;{ }^{*} p<0.05\right)$. Data were expressed as mean $\pm \mathrm{SE}, n=6$.

\section{Conclusions}

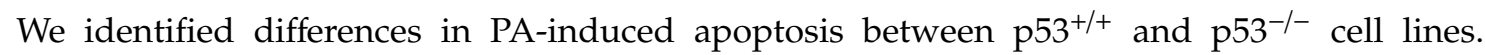
p53 potentially protects cells from PA-induced apoptosis though induction of its target genes, $p 21$ and Sesn2. p21 induces cell cycle arrest, and Sesn2 functions as an antioxidant factor in response to reactive oxygen species induced by PA in p53 wild type cell lines. Expression of $p 21$ and Sesn 2 was higher in p53 wild type cell lines than in p53 null cell lines and loss of p21 leads to more apoptosis in HCT116

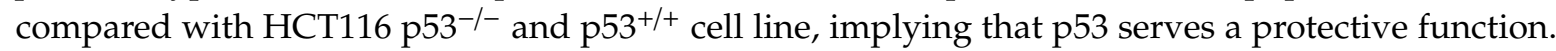
In vivo, we fed a high fat diet to $\mathrm{p} 53^{+/+}$and $\mathrm{p} 53^{-/-}$mice to create a model of obesity. We observed greater glucose resistance in $\mathrm{p} 53^{-/-}$high fat diet mice than in $\mathrm{p} 53^{+/+}$high fat diet mice. p53 potentially protects cells from apoptosis induced by PA stress. This study may open a door to the assessment of healthy diet and p53-related tumor suppression.

Supplementary Materials: Supplementary Materials can be found at http://www.mdpi.com/1422-0067/20/24/ 6268/s1.

Author Contributions: G.Y., Y.T., Y.H. (Yubi Huang) designed the experiments. G.Y., H.L., N.Z., Y.W., Y.L. (Yangping Li) and H.H. performed the experiments. Y.L. (Yinghong Liu), Y.H. (Yufeng Hu), H.L. and J.Z. analyzed the data. G.Y. and Y.T. wrote the paper. All authors have given approval of the final version of the manuscript.

Funding: This study was supported by Youth National Natural Science Foundation of China (31501322), Postdoctoral Special Foundation of Sichuan Province (No:03130104), and overseas project personnel in scientific and technological activities (03109138) to G.W.Y. This study was also supported by NIH/NIGMS grant R01GM112085 to Y.T. This study was also supported by National Natural Science Foundation of China (31971960) and National key research and development program (2016YFD0100503).

Acknowledgments: We thank Bert Vogelstein for HCT116 cells.

Conflicts of Interest: The authors declare no conflict of interest.

\section{Abbreviations}

$\begin{array}{ll}\text { BSA } & \text { bovine serum albumin } \\ \text { MEF } & \text { mouse embryo fibroblasts } \\ \text { OA } & \text { oleic acid } \\ \text { PI } & \text { propidium iodide } \\ \text { ROS } & \text { reactive oxygen species } \\ \text { HCT116 } & \text { human colon carcinoma cells } \\ \text { NAC } & \text { N-Acetyl cysteine } \\ \text { PA } & \text { palmitic acid } \\ \text { PLG } & \text { phase lock gel }\end{array}$




\section{References}

1. Listenberger, L.L.; Ory, D.S.; Schaffer, J.E. Palmitate-induced apoptosis can occur through a ceramide-independent pathway. J. Biol. Chem. 2001, 276, 14890-14895. [CrossRef] [PubMed]

2. Mancini, A.; Imperlini, E.; Nigro, E.; Montagnese, C.; Daniele, A.; Orru, S.; Buono, P. Biological and Nutritional Properties of Palm Oil and Palmitic Acid: Effects on Health. Molecules 2015, 20, 17339-17361. [CrossRef] [PubMed]

3. Ray, K.; Banerjee, H.; Dutta, S.; Hazra, A.K.; Majumdar, K. Macronutrients influence yield and oil quality of hybrid maize (Zea mays L.). PLoS ONE 2019, 14, e0216939. [CrossRef] [PubMed]

4. Wang, H.; Geng, H.; Tang, H.; Wang, L.; Yu, D.; Wang, J.; Song, Y. Enzyme-assisted Aqueous Extraction of Oil from Rice Germ and its Physicochemical Properties and Antioxidant Activity. J. Oleo Sci. 2019, 69, 881-891. [CrossRef] [PubMed]

5. Amalfitano, C.; Golubkina, N.A.; Del Vacchio, L.; Russo, G.; Cannoniero, M.; Somma, S.; Morano, G.; Cuciniello, A.; Caruso, G. Yield, Antioxidant Components, Oil Content, and Composition of Onion Seeds Are Influenced by Planting Time and Density. Plants (Basel) 2019, 8, 293. [CrossRef] [PubMed]

6. Marafie, S.K.; Al-Shawaf, E.M.; Abubaker, J.; Arefanian, H. Palmitic acid-induced lipotoxicity promotes a novel interplay between Akt-mTOR, IRS-1, and FFAR1 signaling in pancreatic beta-cells. Biol. Res. 2019, 52, 44. [CrossRef] [PubMed]

7. Li, X.; Wei, X.; Sun, Y.; Du, J.; Li, X.; Xun, Z.; Li, Y.C. High fat diet promotes experimental colitis by inducing oxidative stress in the colon. Am. J. Physiol. Gastrointest. Liver Physiol. 2019, 317, G453-G462. [CrossRef]

8. Maedler, K.; Spinas, G.A.; Dyntar, D.; Moritz, W.; Kaiser, N.; Donath, M.Y. Distinct effects of saturated and monounsaturated fatty acids on beta-cell turnover and function. Diabetes 2001, 50, 69-76. [CrossRef]

9. Cnop, M.; Hannaert, J.C.; Hoorens, A.; Eizirik, D.L.; Pipeleers, D.G. Inverse relationship between cytotoxicity of free fatty acids in pancreatic islet cells and cellular triglyceride accumulation. Diabetes 2001, 50, 1771-1777. [CrossRef]

10. Karaskov, E.; Scott, C.; Zhang, L.; Teodoro, T.; Ravazzola, M.; Volchuk, A. Chronic palmitate but not oleate exposure induces endoplasmic reticulum stress, which may contribute to INS-1 pancreatic beta-cell apoptosis. Endocrinology 2006, 147, 3398-3407. [CrossRef]

11. Lin, N.; Chen, H.; Zhang, H.; Wan, X.; Su, Q. Mitochondrial reactive oxygen species (ROS) inhibition ameliorates palmitate-induced INS-1 beta cell death. Endocrine 2012, 42, 107-117. [CrossRef] [PubMed]

12. Hardy, S.; Langelier, Y.; Prentki, M. Oleate activates phosphatidylinositol 3-kinase and promotes proliferation and reduces apoptosis of MDA-MB-231 breast cancer cells, whereas palmitate has opposite effects. Cancer Res. 2000, 60, 6353-6358. [PubMed]

13. de Vries, J.E.; Vork, M.M.; Roemen, T.H.; de Jong, Y.F.; Cleutjens, J.P.; van der Vusse, G.J.; van Bilsen, M. Saturated but not mono-unsaturated fatty acids induce apoptotic cell death in neonatal rat ventricular myocytes. J. Lipid Res. 1997, 38, 1384-1394. [PubMed]

14. Zhang, Y.; Xia, G.; Zhang, Y.; Liu, J.; Liu, X.; Li, W.; Lv, Y.; Wei, S.; Liu, J.; Quan, J. Palmitate induces VSMC apoptosis via toll like receptor (TLR)4/ROS/p53 pathway. Atherosclerosis 2017, 263, 74-81. [CrossRef]

15. Shan, X.; Miao, Y.; Fan, R.; Song, C.; Wu, G.; Wan, Z.; Zhu, J.; Sun, G.; Zha, W.; Mu, X.; et al. Suppression of Grb2 expression improved hepatic steatosis, oxidative stress, and apoptosis induced by palmitic acid in vitro partly through insulin signaling alteration. In Vitro Cell Dev. Biol. Anim. 2013, 49, 576-582. [CrossRef]

16. Yuan, Q.; Zhao, S.; Wang, F.; Zhang, H.; Chen, Z.J.; Wang, J.; Wang, Z.; Du, Z.; Ling, E.A.; Liu, Q.; et al. Palmitic acid increases apoptosis of neural stem cells via activating c-Jun N-terminal kinase. Stem Cell Res. 2013, 10, 257-266. [CrossRef]

17. Shimabukuro, M.; Zhou, Y.T.; Levi, M.; Unger, R.H. Fatty acid-induced beta cell apoptosis: A link between obesity and diabetes. Proc. Natl. Acad. Sci. USA 1998, 95, 2498-2502. [CrossRef]

18. Shimabukuro, M.; Koyama, K.; Lee, Y.; Unger, R.H. Leptin- or troglitazone-induced lipopenia protects islets from interleukin 1beta cytotoxicity. J. Clin. Investig. 1997, 100, 1750-1754. [CrossRef]

19. Ostrander, D.B.; Zhang, M.; Mileykovskaya, E.; Rho, M.; Dowhan, W. Lack of mitochondrial anionic phospholipids causes an inhibition of translation of protein components of the electron transport chain. A yeast genetic model system for the study of anionic phospholipid function in mitochondria. J. Biol. Chem. 2001, 276, 25262-25272. [CrossRef] 
20. James, A.; Wang, Y.; Raje, H.; Rosby, R.; DiMario, P. Nucleolar stress with and without p53. Nucleus 2014, 5, 402-426. [CrossRef]

21. Wawryk-Gawda, E.; Chylinska-Wrzos, P.; Lis-Sochocka, M.; Chlapek, K.; Bulak, K.; Jedrych, M.; Jodlowska-Jedrych, B. P53 protein in proliferation, repair and apoptosis of cells. Protoplasma 2014, 251, 525-533. [CrossRef] [PubMed]

22. Chen, J. The Cell-Cycle Arrest and Apoptotic Functions of 553 in Tumor Initiation and Progression. Cold Spring Harb. Perspect. Med. 2016, 6, a026104. [CrossRef] [PubMed]

23. Assaily, W.; Rubinger, D.A.; Wheaton, K.; Lin, Y.; Ma, W.; Xuan, W.; Brown-Endres, L.; Tsuchihara, K.; Mak, T.W.; Benchimol, S. ROS-mediated p53 induction of Lpin1 regulates fatty acid oxidation in response to nutritional stress. Mol. Cell 2011, 44, 491-501. [CrossRef] [PubMed]

24. Olovnikov, I.A.; Kravchenko, J.E.; Chumakov, P.M. Homeostatic functions of the p53 tumor suppressor: Regulation of energy metabolism and antioxidant defense. Semin. Cancer Biol. 2009, 19, 32-41. [CrossRef] [PubMed]

25. Riley, T.; Sontag, E.; Chen, P.; Levine, A. Transcriptional control of human p53-regulated genes. Nat. Rev. Mol. Cell Biol. 2008, 9, 402-412. [CrossRef] [PubMed]

26. Budanov, A.V.; Karin, M. p53 target genes sestrin 1 and sestrin 2 connect genotoxic stress and mTOR signaling. Cell 2008, 134, 451-460. [CrossRef]

27. Shi, Y.F.; Szalay, M.G.; Paskar, L.; Sahai, B.M.; Boyer, M.; Singh, B.; Green, D.R. Activation-induced cell death in T cell hybridomas is due to apoptosis. Morphologic aspects and DNA fragmentation. J. Immunol. 1990, 144, 3326-3333.

28. Desoize, B.; Sen, S. Apoptosis or programmed cell death: Concepts, mechanisms and contribution in oncology. Bull. Cancer 1992, 79, 413-425.

29. Schmid, I.; Uittenbogaart, C.H.; Giorgi, J.V. Sensitive method for measuring apoptosis and cell surface phenotype in human thymocytes by flow cytometry. Cytometry 1994, 15, 12-20. [CrossRef]

30. Sun, Y.; Yang, J.; Liu, W.; Yao, G.; Xu, F.; Hayashi, T.; Onodera, S.; Ikejima, T. Attenuating effect of silibinin on palmitic acid-induced apoptosis and mitochondrial dysfunction in pancreatic beta-cells is mediated by estrogen receptor alpha. Mol. Cell Biochem. 2019, 460, 81-92. [CrossRef]

31. Ohtsubo, K.; Chen, M.Z.; Olefsky, J.M.; Marth, J.D. Pathway to diabetes through attenuation of pancreatic beta cell glycosylation and glucose transport. Nat. Med. 2011, 17, 1067-1075. [CrossRef] [PubMed]

32. Yang, L.; Guan, G.; Lei, L.; Liu, J.; Cao, L.; Wang, X. Oxidative and endoplasmic reticulum stresses are involved in palmitic acid-induced H9c2 cell apoptosis. Biosci. Rep. 2019, 39, 5. [CrossRef] [PubMed]

33. Merkel, O.; Taylor, N.; Prutsch, N.; Staber, P.B.; Moriggl, R.; Turner, S.D.; Kenner, L. When the guardian sleeps: Reactivation of the p53 pathway in cancer. Mutat. Res. 2017, 773, 1-13. [CrossRef] [PubMed]

34. Lane, D.P. Cancer. p53, guardian of the genome. Nature 1992, 358, 15-16. [CrossRef] [PubMed]

35. Bossy-Wetzel, E.; Green, D.R. Detection of apoptosis by annexin V labeling. Methods Enzymol. 2000, 322, 15-18. [PubMed]

36. van Engeland, M.; Nieland, L.J.; Ramaekers, F.C.; Schutte, B.; Reutelingsperger, C.P. Annexin V-affinity assay: A review on an apoptosis detection system based on phosphatidylserine exposure. Cytometry 1998, 31, 1-9. [CrossRef]

37. Marra, F.; Svegliati-Baroni, G. Lipotoxicity and the gut-liver axis in NASH pathogenesis. J. Hepatol. 2018, 68, 280-295. [CrossRef]

38. Win, S.; Than, T.A.; Le, B.H.; Garcia-Ruiz, C.; Fernandez-Checa, J.C.; Kaplowitz, N. Sab (Sh3bp5) dependence of JNK mediated inhibition of mitochondrial respiration in palmitic acid induced hepatocyte lipotoxicity. J. Hepatol. 2015, 62, 1367-1374. [CrossRef]

39. Giorgio, M.; Migliaccio, E.; Orsini, F.; Paolucci, D.; Moroni, M.; Contursi, C.; Pelliccia, G.; Luzi, L.; Minucci, S.; Marcaccio, M.; et al. Electron transfer between cytochrome $\mathrm{c}$ and p66Shc generates reactive oxygen species that trigger mitochondrial apoptosis. Cell 2005, 122, 221-233. [CrossRef]

40. Simon, H.U.; Haj-Yehia, A.; Levi-Schaffer, F. Role of reactive oxygen species (ROS) in apoptosis induction. Apoptosis 2000, 5, 415-418. [CrossRef]

41. Eruslanov, E.; Kusmartsev, S. Identification of ROS using oxidized DCFDA and flow-cytometry. Methods Mol. Biol. 2010, 594, 57-72. [PubMed] 
42. Guri, A.J.; Hontecillas, R.; Bassaganya-Riera, J. Abscisic acid synergizes with rosiglitazone to improve glucose tolerance and down-modulate macrophage accumulation in adipose tissue: Possible action of the cAMP/PKA/PPAR gamma axis. Clin. Nutr. 2010, 29, 646-653. [CrossRef] [PubMed]

43. van der Heijden, R.A.; Sheedfar, F.; Morrison, M.C.; Hommelberg, P.P.; Kor, D.; Kloosterhuis, N.J.; Gruben, N.; Youssef, S.A.; de Bruin, A.; Hofker, M.H.; et al. High-fat diet induced obesity primes inflammation in adipose tissue prior to liver in C57BL/6j mice. Aging (Albany NY) 2015, 7, 256-268. [CrossRef] [PubMed]

44. Mirzayans, R.; Andrais, B.; Kumar, P.; Murray, D. Significance of Wild-Type p53 Signaling in Suppressing Apoptosis in Response to Chemical Genotoxic Agents: Impact on Chemotherapy Outcome. Int. J. Mol. Sci. 2017, 18, 5. [CrossRef]

45. Mirzayans, R.; Andrais, B.; Murray, D. Impact of Premature Senescence on Radiosensitivity Measured by High Throughput Cell-Based Assays. Int. J. Mol. Sci. 2017, 18, 7. [CrossRef]

46. Mirzayans, R.; Andrais, B.; Scott, A.; Wang, Y.W.; Weiss, R.H.; Murray, D. Spontaneous gammaH2AX Foci in Human Solid Tumor-Derived Cell Lines in Relation to p21WAF1 and WIP1 Expression. Int. J. Mol. Sci. 2015, 16, 11609-11628. [CrossRef]

47. Li, T.; Kon, N.; Jiang, L.; Tan, M.; Ludwig, T.; Zhao, Y.; Baer, R.; Gu, W. Tumor suppression in the absence of p53-mediated cell-cycle arrest, apoptosis, and senescence. Cell 2012, 149, 1269-1283. [CrossRef]

48. de la Torre, A.J.; Rogoff, D.; White, P.C. P53 and cellular glucose uptake. Endocr. Res. 2013, 38, 32-39. [CrossRef]

49. Mai, W.X.; Gosa, L.; Daniels, V.W.; Ta, L.; Tsang, J.E.; Higgins, B.; Gilmore, W.B.; Bayley, N.A.; Harati, M.D.; Lee, J.T.; et al. Cytoplasmic p53 couples oncogene-driven glucose metabolism to apoptosis and is a therapeutic target in glioblastoma. Nat. Med. 2017, 23, 1342-1351. [CrossRef]

50. Sablina, A.A.; Budanov, A.V.; Ilyinskaya, G.V.; Agapova, L.S.; Kravchenko, J.E.; Chumakov, P.M. The antioxidant function of the p53 tumor suppressor. Nat. Med. 2005, 11, 1306-1313. [CrossRef]

51. Kang, M.Y.; Kim, H.B.; Piao, C.; Lee, K.H.; Hyun, J.W.; Chang, I.Y.; You, H.J. The critical role of catalase in prooxidant and antioxidant function of p53. Cell Death Differ. 2013, 20, 117-129. [CrossRef] [PubMed]

52. Popowich, D.A.; Vavra, A.K.; Walsh, C.P.; Bhikhapurwala, H.A.; Rossi, N.B.; Jiang, Q.; Aalami, O.O.; Kibbe, M.R. Regulation of reactive oxygen species by p53: Implications for nitric oxide-mediated apoptosis. Am. J. Physiol. Heart Circ. Physiol. 2010, 298, H2192-H2200. [CrossRef] [PubMed]

53. Johnson, T.M.; Yu, Z.X.; Ferrans, V.J.; Lowenstein, R.A.; Finkel, T. Reactive oxygen species are downstream mediators of p53-dependent apoptosis. Proc. Natl. Acad. Sci. USA 1996, 93, 11848-11852. [CrossRef] [PubMed]

54. Tanaka, H.; Arakawa, H.; Yamaguchi, T.; Shiraishi, K.; Fukuda, S.; Matsui, K.; Takei, Y.; Nakamura, Y. A ribonucleotide reductase gene involved in a p53-dependent cell-cycle checkpoint for DNA damage. Nature 2000, 404, 42-49. [CrossRef]

55. Hollander, M.C.; Alamo, I.; Jackman, J.; Wang, M.G.; McBride, O.W.; Fornace, A.J., Jr. Analysis of the mammalian gadd45 gene and its response to DNA damage. J. Biol. Chem. 1993, 268, 24385-24393.

56. Das, S.K.; Mondal, A.K.; Elbein, S.C. Distinct gene expression profiles characterize cellular responses to palmitate and oleate. J. Lipid Res. 2010, 51, 2121-2131. [CrossRef]

57. Georgakilas, A.G.; Martin, O.A.; Bonner, W.M. p21: A Two-Faced Genome Guardian. Trends Mol. Med. 2017, 23, 310-319. [CrossRef]

58. Mirzayans, R.; Andrais, B.; Scott, A.; Wang, Y.W.; Murray, D. Ionizing radiation-induced responses in human cells with differing TP53 status. Int. J. Mol. Sci. 2013, 14, 22409-22435. [CrossRef]

59. Mirzayans, R.; Andrais, B.; Murray, D. Viability Assessment Following Anticancer Treatment Requires Single-Cell Visualization. Cancers (Basel) 2018, 10, 255. [CrossRef]

60. Spector, A.A. Structure and lipid binding properties of serum albumin. Methods Enzymol. 1986, 128, 320-339.

(C) 2019 by the authors. Licensee MDPI, Basel, Switzerland. This article is an open access article distributed under the terms and conditions of the Creative Commons Attribution (CC BY) license (http://creativecommons.org/licenses/by/4.0/). 